\title{
THE INFLUENCE OF LIMESTONE AND CALCIUM HYDROXIDE ADDITION IN ASPHALT CONCRETE MIXTURE
}

\author{
Gunaran Danny ${ }^{1}$; Nasus K. Y. ${ }^{2}$; Napitupulu J. P. F. ${ }^{3}$; Amelia Makmur ${ }^{4}$ \\ 1,2,3,4 Civil Engineering Study Program, Faculty of Engineering and Computer Science, \\ Krida Wacana Christian University, \\ Jl. Tanjung Duren Raya No. 4, Jakarta Barat, 11470 \\ 11danny.2012ts003@civitas.ukrida.ac.id; 2yohanes.2012ts013@civitas.ukrida.ac.id; \\ 3josep.2012ts018@civitas.ukrida.ac.id; ${ }^{4}$ amelia@ukrida.ac.id
}

\begin{abstract}
As time passes, flood often occurs in the area of Gunung Sahari, Jakarta Utara. The flood damages concrete asphalt mixture and it needs particular improvement. Therefore, the purpose of this research is to know the effects of the added combination of limestone and calcium hydroxide on concrete asphalt mixture as a filler resistant to flood. Concrete asphalt mixture that filled with the combination of limestone and calcium hydroxide is a mixture that is made with non-uniform aggregat gradations, filler and liquid asphalt mixed and solidified in a heat state. Limestone and calcium hydroxide mixture is used because both materials included in the most numerous sedimentary rock. Concrete asphalt mixture with the filler combination of limestone and calcium hydroxide is made with optimum asphalt $5.4 \%$, one variation level of limestone (15\%), and calcium hydroxide (15\%), and three variation levels of fillers (5\%, 7.5\%, and 15\%) to get optimum asphalt levels and filler levels that are compatible with flood condition. Based on optimum asphalt $5.4 \%$ towards aggregate total weight and combined level of limestone and calcium hydroxide suitable for the conditions, $8.75 \%$ towards fine aggregate weight. The characteristic value of limestone and calcium hydroxide mixture in maximum condition is VIM $4.55 \%$, VMA $18.83 \%$, stability $1031.26 \mathrm{~kg}$ and flow $4.93 \mathrm{~mm}$, where the characteristic value meets the established specifications standard by Pekerjaan Umum Bina Marga. From the result, it is showed that the use of the mixture can decrease the value of stability and increase the value of flow, compared with asphalt and filler with normal levels.
\end{abstract}

Keywords: limestone, calcium hydroxide, filler, stability, flow, durability

\section{INTRODUCTION}

Rain makes asphalt road to become damage with potholes. Rain causes water drainage to be overflown and causes long-term flood. The asphalt has an anti-water characteristic, which causes water to be hard to be integrated with its material, since it was made from oil and thus water can not integrated with it. Then the asphalt function as a binder becomes fail while water damps it. When asphalt loses it function as a binder, the aggregates slips through and the road can not do the function. Alternatively, the aggregates can be changed with the other materials which helps to be more strong binding its system. Some of them known as limestones. Limestone is one of largest amount stone has ever found. It also used as a filler of asphalt concrete. This kind of stone has many function in construction material, such as stabilization of highway foundation (Wesley, 2010). Limestone contains $\mathrm{CaCO}_{3}$ (Calcium Carbonate) which is formed into rock and refined objects (fine grain shape). Limestone that can be found in nature is a magnesium limestone. There are some characteristic of limestone, including: (1) Color: White, brown white, and grey white, (2) Polish: Glass, and soil. (3) Scratch: White to grey white. (4) Split part/split field: Non-regular / irregular. (4) Fraction: Uneven / unequal. (5) Force: 2.7 - 3.4 Mohs. (6) Specific Gravity: 2.387t $/ \mathrm{m}^{3}$. (7) Characteristics: Hard, compact, partly space. (8) Description: Mohs scale of mineral hardness classifies the stroke ressistance against various mineral through the ability of a material is hard, scrape the ingredients are more lenient. The research of limestone use fine grain shape and quality No. 200. 
Limestone is Tohor limestone (Calcium Oxide, $\mathrm{CaO}$ ) that watered to produce heat and become hydrated lime (Calcium Hydroxide, $\mathrm{CaOH}$ ). This stone is used as a binder hydrolic which mixed with water and form into paste that will harden and unable to dissolve back in water (Hidayat, 2012). These mixing parts, such as limestone and hydrated lime can be used as a filler in the asphalt concrete. Therefore those functions can be described more in this research. Filler influences the optimum asphalt through the surface area of the particles vast grounds, so that the properties of the surface will modify the asphalt characteristic, for example; the penetration, dactility, and resilience (Kumalawati, Tri and Mastaram, 2013). Meanwhile, the type and quantity of filler also influence the quality of its mortar or paste. Except the fillers, adding materials such as chemical like polymer impact against the characteristics of asphalt concrete mixture (Achmad \& Sutjahjo, 2011). This 1 shows specification of asphalt modification.

Table 1 Specification of Modificate Asphalt

\begin{tabular}{lc}
\hline \multicolumn{1}{c}{ Parameter } & Description \\
\hline Bulk Specific Gravity & $\min 2 \mathrm{gr} / \mathrm{cm}^{3}$ \\
VIM & $3.5-5.5 \%$ \\
VMA & $>15 \%$ \\
VFA & $\min 65 \%$ \\
Stability & $1000-1800 \mathrm{~kg}$ \\
Flow & $3-5 \mathrm{~mm}$ \\
\hline
\end{tabular}

Samples are made from main test performed using Marshall method. The Marshall method is a method which combines a hot asphalt concrete with an absolute density approach. There are seven characteristics of asphalt concrete mixture: stability, durability, flexibility, fatigue resistance, surface skid resistance, waterproof function, and easy to be carried out (Edison, 2010). Stability is the ability of an asphalt mixture to receive the load until the load fatigue occurs. Fatigue is a state of plasticity changes form an asphalt mixture that results from a load limit collapses stated in mm, or 0.01". Durability is the ability of a paved mixture that can last from disintegration due to traffic load and the change of asphalt due to oxidation. Suppleness (flexibility) is the ability to adjust the shape of the deformation due to gradual traffic loads without experiencing the rift and change of volume (Tahir, 2009). Skid resistance is the ability to make the road surface to be anti-slip (not slippery). Those characteristics made impact for the performance of asphalt mixture so that the terms will degrade the performance of asphalt mixture (Suroso, 2009).

The purpose of the research is to inform about the influence by adding a mixture of limestone and lime on asphalt concrete mix, and to know the value of the stability and durability of asphalt concrete mixed with a filler of limestone and calcium hydroxide combined outages, as well as finding the levels of a mixture that are suitable for the circumstances of flood around Gunung Sahari, North Jakarta. The advantage of this research is to learn more about the asphalt mixture from the joint filler of limestone and calcium hydroxide of the outages to flood in Gunung Sahari, North Jakarta, and to learn about the strength and durability of them.

\section{METHODS}

The research experiment refers to the Indonesia National Standard. Indonesia National Standard used within this research includes: SNI 03-1968-1990, SNI 03-1969-1990, SNI 03-19701990, SNI 03-1971-1990, SNI 03-2417-1991, SNI 03-2441-1991, SNI 03-2439-1991, SNI 06-24891991, SNI 06-2456-1991. Other procedures that are not included in SNI use procedures that are 
commonly used, namely Bina Marga, AASHTO, etc. The research method used quantitative methods where the characteristics of asphalt mixtures were taken from samples that were created and analyzed in accordance with the obtained data. Then, it would be conducted by Marshall method which began with 1 asphalt levels i.e. 5.4\% and 1 levels of various type of materials that consisted of limestone and calcium hydroxide as well as the 3 levels of combined ingredients of limestone and calcium hydroxide. The number of test objects for each of the levels are 5 pieces with a total weight of aggregates for 1 piece of test objects is 1200 grams and using the 2x75 compacting method. The completed test objects were weighed (dry) and weighed under the water prior to the immersion for an hour. After the immersion for an hour, saturated surface-dry (SSD) weighing was done. The test objects were soaked again in water bath with a temperature of $60{ }^{\circ} \mathrm{C}$, then a test to get value of stability and flow from the test objects was performed using the Marshall equipment.

Presented writing systematics includes abstract, introduction, methods, results and discussion, conclusions and references. Abstract contains a summary of the study conducted to provide clear and concise information. Introduction describes the background of the research and information concerning materials that were used. Method includes the method used in writing the research and methods used to conduct the research. Results and discussion contain the results obtained that will be discussed and analyzed in accordance with the references. The conclusion lays out the core of the research that has been done to get the clear conclusions.

\section{RESULTS AND DISCUSSIONS}

The research uses 25 samples with each of the different levels. The composition of the levels that are used with $5.4 \%$ asphalt rate is $10 \%$ limestone, $10 \%$ Calcium hydroxide, $5 \%-15 \%$ with a $5 \%$ increase of limestone and Calcium hydroxide. Each test object is done by bulk specific gravity, VIM, VMA, VFA, stability, and flow. The result of these tests is presented in Figure 1 below.

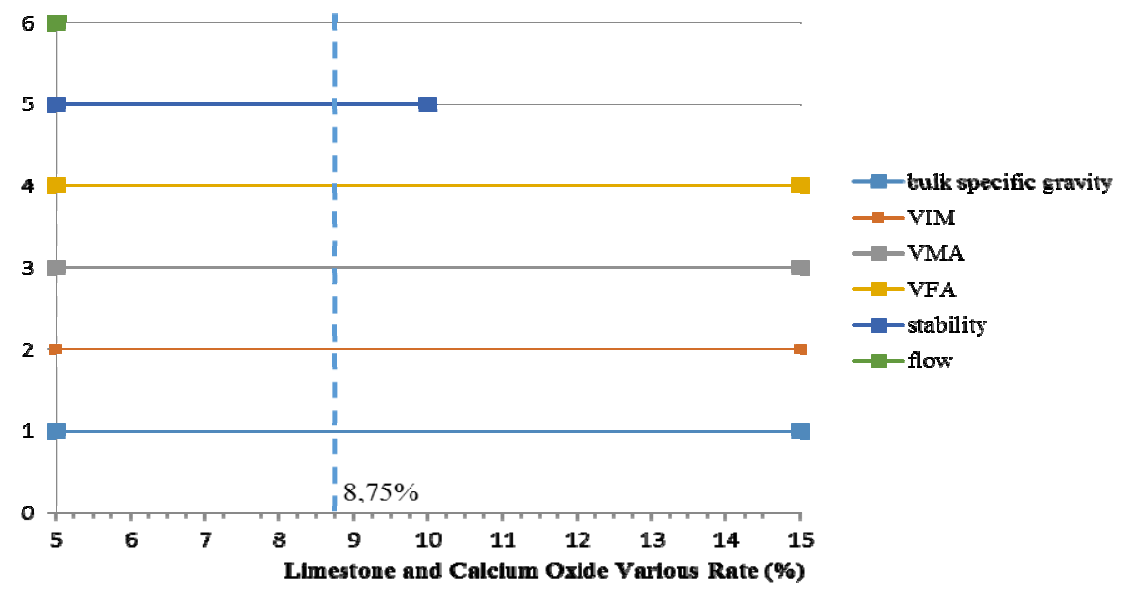

Figure 1 The Value of Limestone and Calcium Hydroxide Mixture

The levels of the mixture between limestone and calcium hydroxide in Figure 2 shows that the additional mixture of limestone and calcium hydroxide increased stability and decreased the flow on the percentage of $8.75 \%$. The percentage led to the left part since the flow and stability do not meet the determined standard thus the percentage led to smaller percentage. On the other hand, bulk specific gravity, VIM, VMA, and VFA showed that all the samples in accordance with the standards of SNI, 
thus Figure 3 is represented up to $15 \%$. The withdrawal of $8.75 \%$ is based on the six parameters of the testing that has been done to produce the optimum levels of limestone and calcium hydroxide on the percentage.

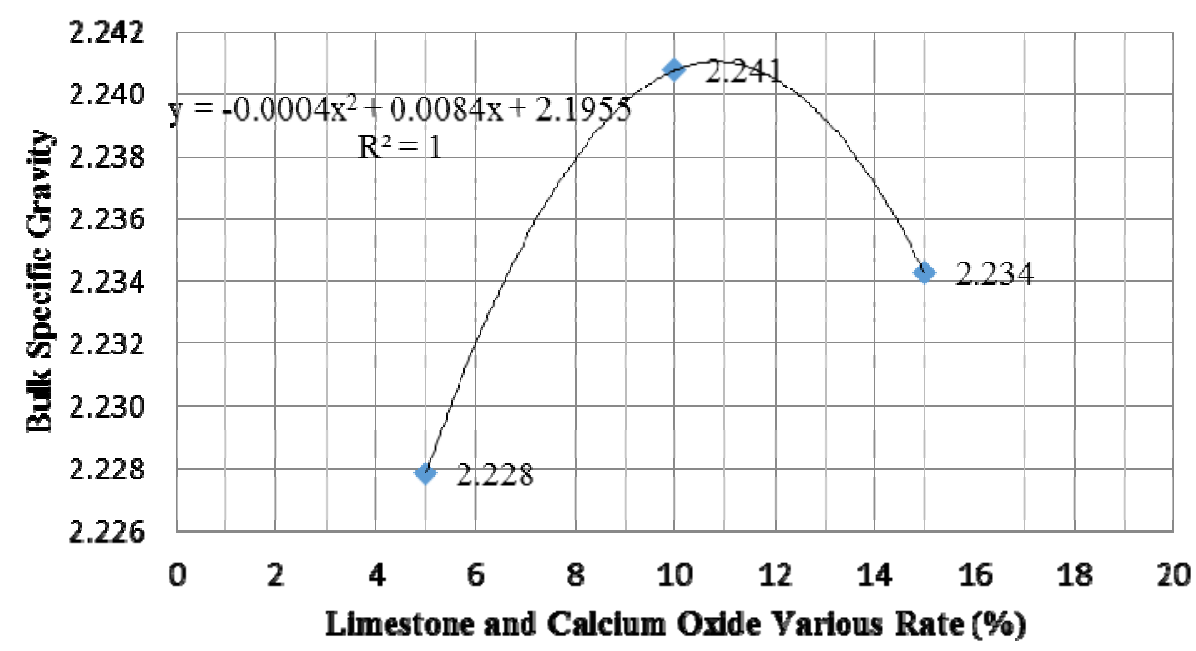

Figure 2 Bulk Specific Gravity

Bulk specific gravity indicates that there is a rise in the rate of $5 \%-10 \%$. The specific gravity on each of the asphalt levels gains the requirements of SNI 06-2489-1991 at least $2 \mathrm{gr} / \mathrm{cm}^{3}$. Bulk specific gravity values indicate the magnitude of the density of a mixture from asphalt and their aggregates already pounded or compacted and have the ability to withstand load (Sukirman, 2012). Figure 2 shows the increase in the bulk specific gravity of 5\%-10\%. Parabolic line showed regression of the data distribution.

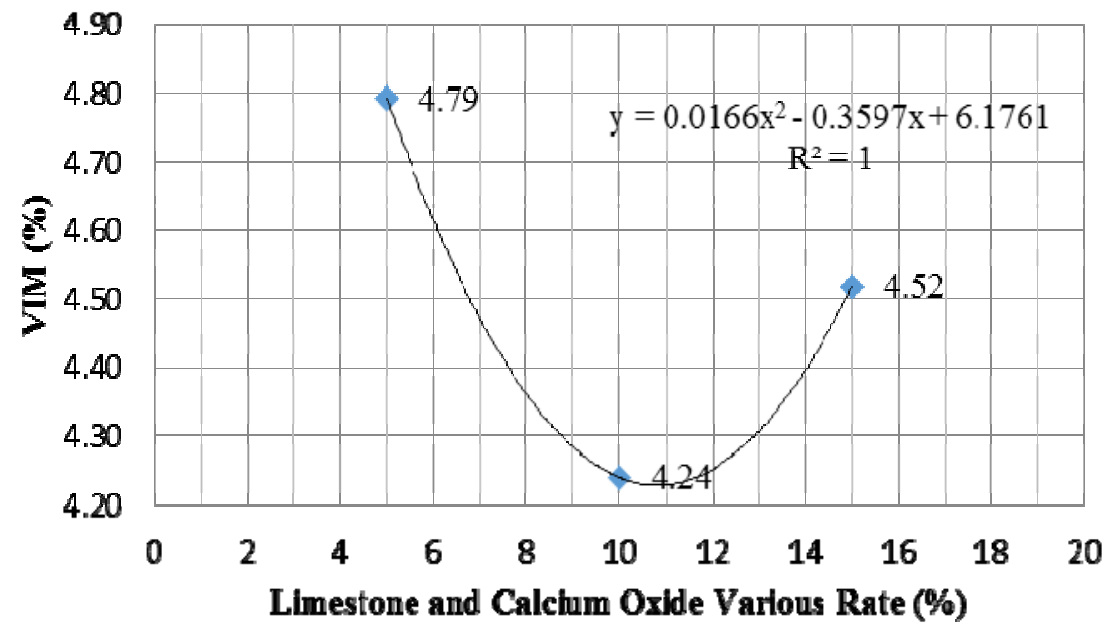

Figure 3 The VIM of Limestone and Calcium Hydroxide Mixture

Figure 4 shows that there is a degression at the rate of $5 \%-10 \%$. When the value of VIM is smaller, the more impermeable the layer to water and air. Beside that, the greater the quantity of a mixture from limestone and calcium hydroxide then the lower the VIM except at the rate of $15 \%$. The 
existence of the filler mixture closes the cavity of the asphalt mixture and proportionates with the decreasing VIM graphic data.

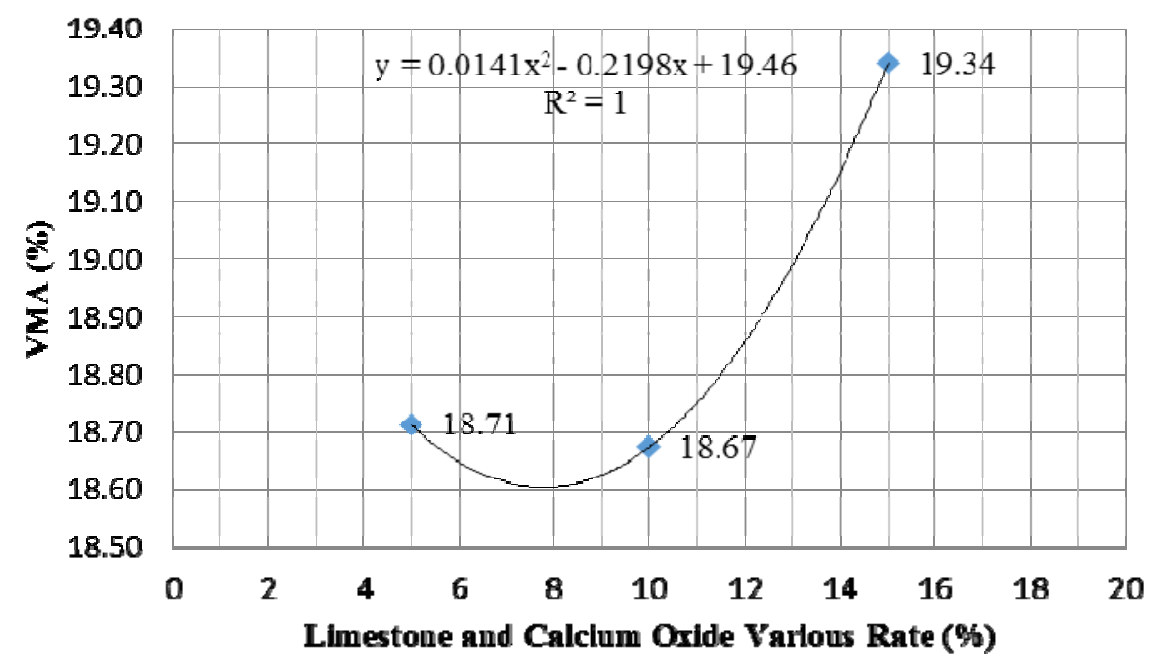

Figure 4 The VMA of Limestone and Calcium Hydroxide Mixture

The data obtained in the VMA has a raise from $10 \%-15 \%$ limestone and calcium hydroxide mixture. VMA is the volume of the cavity between the particles in the asphalt concrete. All VMA meet the requirements, that is, to be greater than $15 \%$. With the addition of limestone and calcium hydroxide, the volume of the cavity between aggregate particles becomes larger making the mixture to be filled up with grey, fine aggregate and the filler that were added.

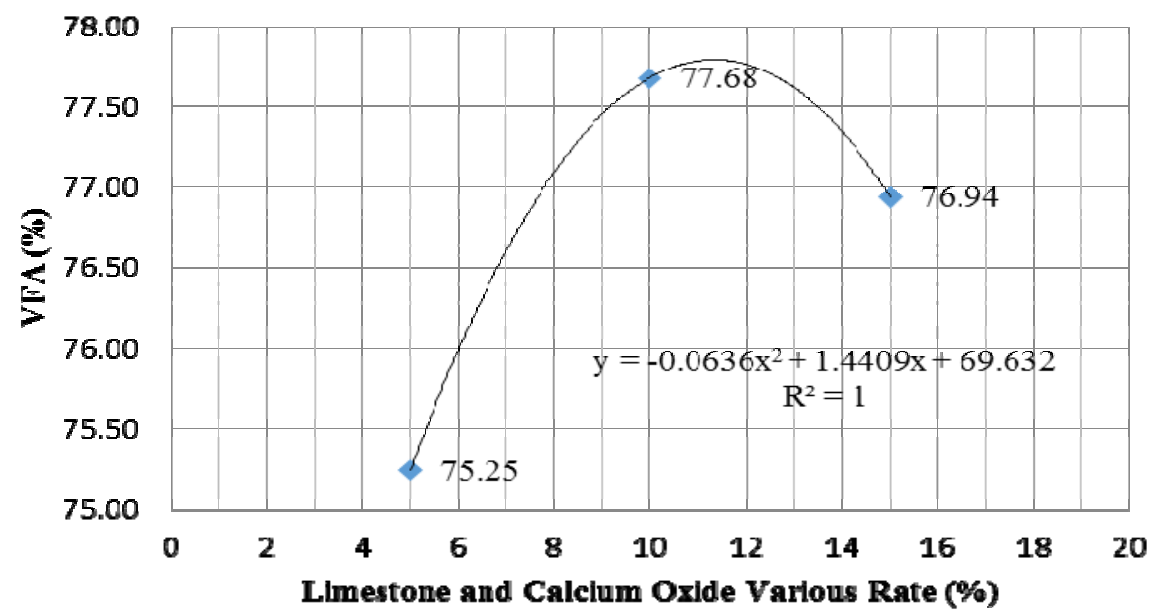

Figure 5 The VFA of Limestone and Calcium Hydroxide Mixture

The VFA shows that $5 \%-15 \%$ asphalt is included in the requirements, that is, to be more than or equal to $65 \%$. The better the mixture, the greater the VFA. Liquid asphalt would fill the cavities requiring a bond between the particles to merge the materials into one. 


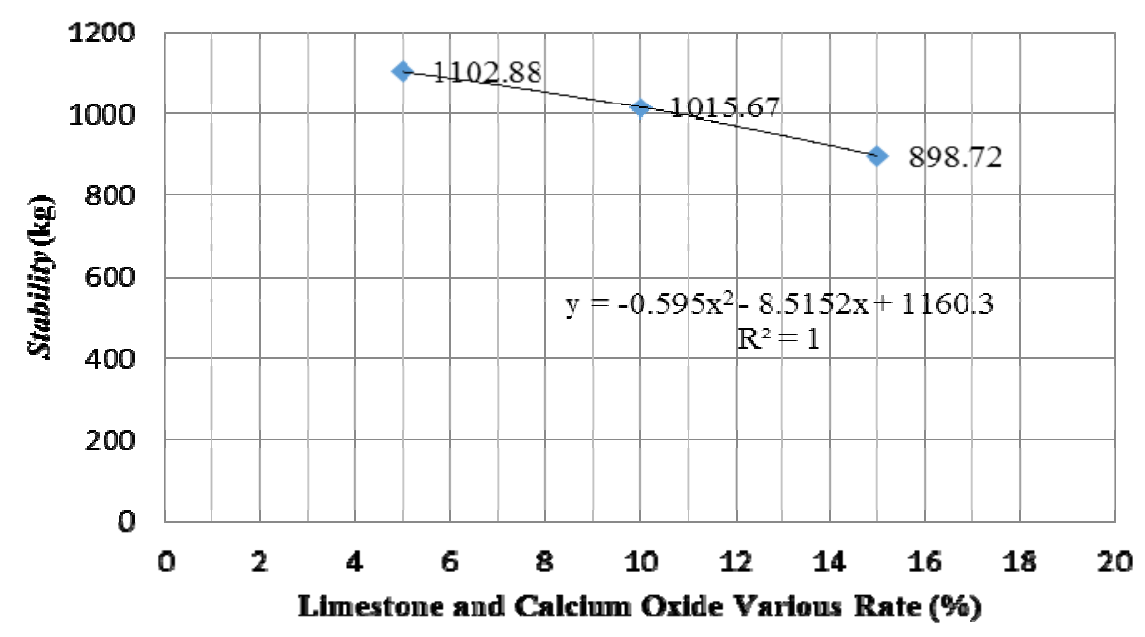

Figure 6 The Stability of Various Limestone and Calcium Hydroxide Mixture

Figure 6 shows a graph of the relationship of the stability from various levels. The greater the quantity of a limestone and calcium hydroxide mixture, the smaller the stability. The decreasing stability can be seen in Figure 6 which shows that every addition from filler caused the stability to decline from 1102,88 $\mathrm{kg}$ to $898,72 \mathrm{~kg}$. At the rate of $15 \%$, limestone and calcium hydroxide do not reach the specification of normal asphalt mixture making the addition of mixture is not recommended. With the additional rate of 5\%, it decreases a stability ranged from 80-120 kg.

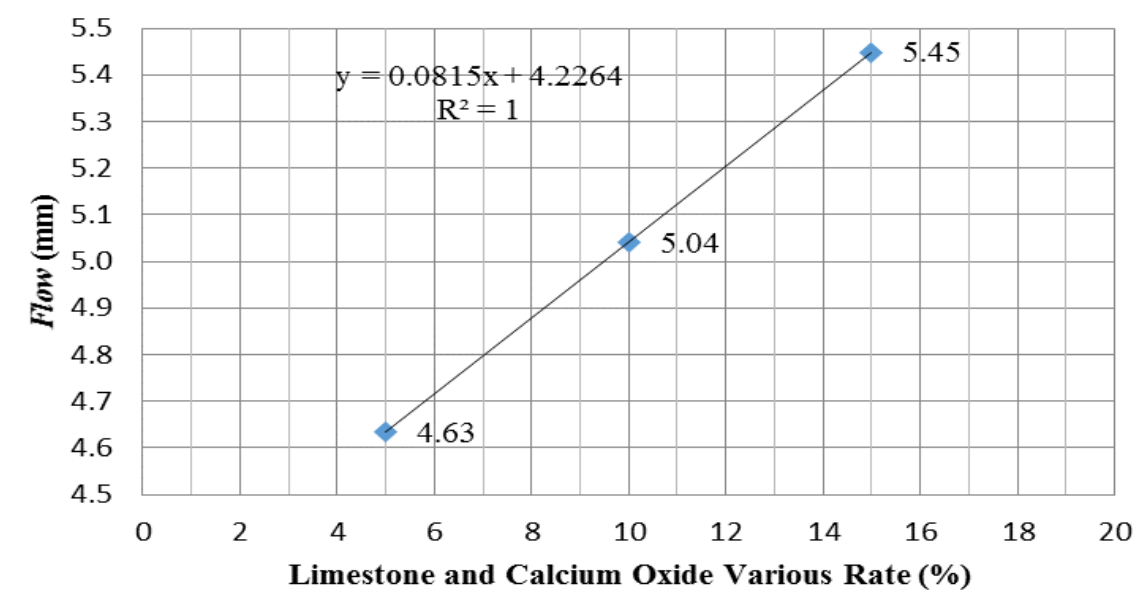

Figure 7 The Flow of Various Limestone and Calcium Hydroxide Mixture

The flow on the result is steadily increasing for limestone and calcium hydroxide mixture. The flow from each level does not all fit in the requirements, that is between $10 \%-15 \%$. However, the flow from the $5 \%$ mixture is included in the requirements. The flow is inversely proportional to the stability because the higher the stability, it will lower the flow that generated in accordance with the increasing levels of a mixture.

The calculation result of the optimal mixture based on the test results for each Marshall parameter that meets the standard includes: bulk specific gravity 5\%-15\%, VIM 5\%-15\%, VMA 5\%$15 \%$, VFA $5 \%-15 \%$, stability $5 \%-10 \%$ and flow $5 \%$. The values are taken from the average values. Thus, the optimum levels of a mixture of limestone and calcium hydroxide for $5.4 \%$ asphalt is $8.75 \%$. 
Table 2 Limestone and Calcium hydroxide Rate Compatible with Specification

\begin{tabular}{cccccrcc}
\hline Asphalt Rate & Density & VIM & VMA & VFA & Stability & Flow & Quotient Marshall \\
\hline 5,40 & 2,23 & 4,79 & 18,71 & 75,25 & 1102,88 & 4,63 & $\mathbf{2 3 8 , 0 1}$ \\
5,40 & 2,24 & 4,24 & 18,67 & 77,68 & 1015,67 & $\mathbf{5 , 0 4}$ & $\mathbf{2 0 1 , 4 8}$ \\
5,40 & 2,23 & 4,52 & 19,34 & 76,94 & $\mathbf{8 9 8 , 7 2}$ & $\mathbf{5 , 4 5}$ & $\mathbf{1 6 4 , 9 5}$ \\
\hline Specification & min 2 & $\mathbf{3 . 5}-\mathbf{5 . 5}$ & $>\mathbf{1 5}$ & $\mathbf{m i n} \mathbf{6 5}$ & $\mathbf{1 0 0 0} \mathbf{~ k g}$ & $\mathbf{3 - 5} \mathbf{~ m m}$ & $\mathbf{m i n} \mathbf{3 0 0}$ \\
\hline
\end{tabular}

Description:

Bold writings has no effect to the technical specifications of the average levels, the optimum asphalt = $8.75 \%$. Samples that do not reach the technical specifications average shows the limit of one sample which could not raise or lower the required specifications. For stability, a minimum of $1000 \mathrm{~kg}$ is required, however the more it is added, the mixture of limestone and calcium hydroxide is declined. Thus, the addition of more than $15 \%$ is not needed. While the melting point occurred, the rate of $5 \%$ is still within the limits of the specification and if the percentage rises to $10 \%$ the melting point does not include in the specifications.

The comparison value between stability and melting point is also not inputted because the value of melting point already exceeds the standard limits. The value of density, VIM, VMA, and VFA input in the specifications so that the addition of asphalt mixture by using a combination of limestone can be various at different levels. Like the increase levels of limestone and calcium hydroxide to the levels of the asphalt itself, represents the levels of asphalt which is used when the optimum conditions on the normal asphalt mixture obtained is $5.4 \%$.

\section{CONCLUSIONS}

The level value of mixture from limestone and optimum calcium hydroxide with Marshall test results is $8.75 \%$. Compared to the stability of pure limestone and pure calcium hydroxide, greater stability on a mixture is obtained. With a basic understanding of existing theory that both materials can be fused together as it has the same element like Ca (calcium), then both materials can be fused and become filler on an existing mixture and resistant to load. If it is compared with a mixture without limestone and calcium hydroxide, the stability of normal mixture is $1400,00 \mathrm{~kg}$, lower than the mixture fused with limestone and calcium hydroxide.

In addition, some other conclusion that can be drawn from the results of this test are: (1) the combined usage of limestone and calcium hydroxide on asphalt concrete mixture would increase the bulk specific gravity of asphalt mixture, increases the value of the VIM and VMA, raises the melting point of asphalt concrete but also lowers the value of the VFA and the stability of asphalt concrete. (2) The combined levels of limestone and calcium hydroxide 5\% can generate the highest stability value that is in the amount of $1102.88 \mathrm{~kg}$. There is a degression in the value of stability that is not using a combination of limestone and calcium hydroxide. (3) Level of limestone and calcium hydroxide with asphalt concrete $5.4 \%$ is $8.75 \%$. The mixture of limestone and calcium hydroxide is not recommended because it may decrease stability even though it increases the flow or melting point of asphalt concrete. It is suggested to add addictive substances and level proportions which far greater than before, for example: limestone levels should be greater than the calcium hydroxide. 


\section{REFERENCES}

Achmad, D., \& Sutjahjo, K. D. (2011). Dampak Penambahan Polimer Terhadap Karakteristik Beton Aspal. Poli Teknologi, 10(1), 32-38.

Edison, B. (2010). Karakteristik Campuran Aspal Panas (Asphalt Concrete-Binder Course) Menggunakan Aspal Polimer. Jurnal APTEK, 2(1), 60-71.

Hidayat, A. (2012, 10 January). Pemanfaatan Batu Gamping (Batu Kapur) Sebagai Barang Ekonomis Non Logam. Retrieved on May 25, 2014 from http://www.ariefgeo.blogspot.com/2012/01/pemanfaatan-batugamping-batu-kapur.html

Kumalawati, A., Tri M. W., \& Mastaram, Y. (2013). Analisis Pengaruh Penggunaan Abu Batu Apung Sebagai Pengganti Filler Untuk Campuran Aspal. Jurnal Teknik Sipil, II(2), 191-200.

SNI 03-1968-1990, Metode Pengujian Analisis Saringan Agregat Halus dan Kasar. PusjatanBalitbang PU.

SNI 03-1969-1990, Metode Pengujian Berat Jenis dan Penyerapan Air Agregat Kasar. PusjatanBalitbang PU.

SNI 03-1970-1990, Metode Pengujian Berat Jenis dan Penyerapan Air Agregat Halus. PusjatanBalitbang PU.

SNI 03-1971-1990, Metode Pengujian Kadar Air Agregat. Pusjatan-Balitbang PU.

SNI 03-2417-1991, Metode Pengujian Keausan Agregat dengan Mesin Abrasi Los Angeles. PusjatanBalitbang PU.

SNI 03-2439-1991, Metode Pengujian Kelekatan Agregat terhadap Aspal. Pusjatan-Balitbang PU.

SNI 06-2441-1991, Metode Pengujian Berat Jenis Aspal Padat. Pusjatan Balitbang PU.

SNI 06-2456-1991, Metode Pengujian Penetrasi Bahan-Bahan Bitumen. Pusjatan Balitbang PU.

SNI 06-2489-1991, Metode Pengujian Campuran Aspal Dengan Alat Marshall. Pusjatan-Balitbang PU.

Sukirman, S. (2012). Beton Aspal Campuran Panas. Bandung: Institut Teknologi Nasional.

Suroso, T. W. (2009). Pengaruh Penambahan Plastik LDPE (Low Density Poly Ethilen) Dengan Cara Basah dan Cara Kering Terhadap Kinerja Campuran Beraspal. Jurnal Jalan dan Jembatan, 26(2), 1-16.

Tahir, A. (2009). Karakteristik Campuran Beton Aspal (AC-WC) dengan Menggunakan Variasi Kadar Filler Abu Terbang Batu Bara. Jurnal SMARTek, 7(4,) 256-278.

Wesley, L. D. (2010). Mekanika Tanah untuk Tanah Endapan \& Residu. Yogyakarta: Andi Yogyakarta. 